\title{
A nemzetiségi tanítóképzés története
}

\section{Márkus Éva}

ELTE Tanító- és Óvóképző Kar, habil. egyetemi docens, e-mail: markus.eva@tok.elte.hu

A tanulmány a nemzetiségi tanítóképzés 200 éves történetét és jelenét mutatja be, országos helyzetképet adva. Néhány, az elemzett témában fordulópontot jelentó tanitóképzó intézet története részletesebben is bemutatásra kerül. Az elemzésben két szempont vezérli a tanulmány szerzőjét, a tannyelv kérdése és a törvényi szabályozás mentén járja körül a témát. Vázolja a tanitási nyelv változásának lépéseit és bemutatja azokat a fontosabb törvényeket, amelyek hatással voltak és vannak a nemzetiségek oktatása számára kialakitott tanitóképzésre.

Kulcsszavak: nemzetiségek, tanitóképzés, tanitóképző intézetek, nyelvoktatás, tannyelv, törvényi szabályozás

DOI: 10.37205/TEL-hun.2019.ksz.03

\section{Bevezetés}

Írásomban a 150 éves állami tanítóképzés keretein túlnyúlva, 50 évvel korábban kezdem a nemzetiségi képzés történetét felvázolni. A 200 éves tanítóképzés azon szeletét fogom bemutatni, amely a nemzetiségi tanítók képzésére vonatkozik. A rendelkezésre álló rövid időben bővebb kifejtésre nincs mód, így két szempont, a tannyelv kérdése és a törvényi szabályozás mentén fogom megvizsgálni a témát, országos helyzetképet adva. A nemzetiségi tanítóképzés 200 éves történetének és jelenének bővebb, méltó bemutatására egy az ELTE Tanító- és Óvóképző Karán megrendezésre került konferencia adott módot, 2019. november 15-én. A konferenciát az ELTE Tanító- és Ovóképző Kar és a Pécsi Tudományegyetem Kultúratudományi, Pedagógusképző és Vidékfejlesztési Kar közösen szervezte.

Napjainkban a nemzetiségi oktatás a következőket jelenti: a nemzetiségi tanulók számára létesített intézményes nevelés-oktatás, amelynek feladata, hogy szervezetten biztosítsa a nemzetiségi nyelv tanulását, a nemzetiségi történelem, kultúra, hagyomány megismerését a közösségi identitástudat megőrzése, ápolása, erősítése mellett. A sajátos célok és követelmények teljesítéséhez, a müködés feltételeihez az állam emelt normatív támogatást nyújt (Báthory \& Falus, 1997, p. $558)$. 
200 évvel ezelőtt egészen más volt a helyzet, a nemzetiségi nyelven tanulás és tanítás teljesen természetes volt az ország nemzetiségek lakta területein, hiszen akkor még a nemzetiségi nyelvet anyanyelvükként beszélték a hazánkban élő nemzetiségek; az állam nem támogatta külön a nemzetiségi oktatást. Vagyis nem ugyanazt jelentette a nemzetiségi oktatás akkor és ma, viszont mivel ez a múltban is egy nemzetiségek számára szóló oktatás, képzés volt, ebből a szempontból tekinthető nemzetiségi tanítóképzésnek.

\section{A kezdet: Szepeskáptalan}

Szepeskáptalanban 1819 őszén megnyílt első önálló, más oktatási intézményekkel kapcsolatban nem álló német tannyelvű egyházi tanítóképző intézet (Kovács \& Grundig de Vazques, 2011, p. 34), alapítója Pyrker János László szepesi püspök volt. Más források szerint az első középfokú, önálló tanítóképző Szepesváralján nyílt meg, melynek tanítási nyelve német és szlovák volt (Neszt, 2014, p. 13).

A férfi tanítóképezdében a tanfolyam 2 évig tartott, és 1840-ig összesen 128 tanító kapott itt tanítóképesítő bizonyítványt (Kiss, 1929a, p. 34). A nagy műveltségű püspök jelentős pénzadománnyal vetette meg az anyagi alapot, melyet az egyházmegye papsága jelentős összeggel kiegészített. Az intézmény az ősi Árpádkori székesegyház szomszédságában kapott épületet (Mészáros, 1984, p. 277). Az első képző intézet történetét részletesebben ismerteti Márkus és M. Pintér (2019).

\section{A tanítás nyelve}

\section{A tanítás nyelve -1848}

A 13 magyar nyelvű képző mellett (57\%) a következő nemzetiségi tannyelvű tanítóképző intézetek működtek Magyarországon. Mindegyik képző egyházi volt. A felsorolásban első helyen a székhely áll, utána a fenntartó felekezet neve, majd a képző jellege abból a szempontból, hogy kik járhattak oda (férfi), utána az alapítás éve, végül a tanítás nyelve:

1. Beszterce, evangélikus, férfi, 1847, német,

2. Brassó, evangélikus, férfi, 1847, német,

3. Felsőlövő, evangélikus, férfi, 1845, német,

4. Nagyszeben, evangélikus, férfi, 1847, német

5. Szepesváralja, római katolikus, férfi, 1819, szlovák,

6. Nagyrőcze, evangélikus, férfi, 1847, magyar-szlovák, 
7. Arad, görögkeleti, férfi, 1812, román,

8. Nagyvárad, görög katolikus, férfi, 1847, román,

9. Ungvár, görög katolikus, férfi, 1831, magyar-rutén,

10. Zombor, görögkeleti, férfi, 1816, szerb (Neszt, 2014, p. 39).

\section{A tanítás nyelve - 1856}

A tanítás nyelve a tanítóképzőkben azon a meggondoláson alapult, hogy a tanítójelöltek azon a nyelven tanuljanak, amelyen majd tanítani fognak. A következő felsorolásból látszik, hogy az 1856. január 20-án kelt rendelet szerint hol, milyen vegyes tannyelvủ képzőt találunk Magyarországon. A nemzetiségek lakta vidékeken előfordulhatott, hogy nem tanítottak egyáltalán magyarul, mivel a második nyelv kötelezően a német volt (Neszt, 2014, p. 45) minden képző intézetben:

- Kalocsa, Esztergom, Pécs: magyar - német,

- Pesti képzők: német (egyes tárgyakat magyarul is lehetett tanítani),

- Nagyszombat, Kassa, Besztercebánya: német - tót,

- Sopron: német - horvát,

- Ungvár: magyar - német - ruthén,

- Nagyvárad: német - oláh (gör.kat. képző), Arad: német - oláh (gör.kel. oláh képző),

- Versec, Zombor: német - szerb,

- Nagyvárad, Szatmár, Győr: magyar (a német egyenjogú a magyarral) (Kiss 1929b: 109).

„A tanítóképzők tanítási nyelvei között az önkényuralom céljainak megfelelően, a német nyelv került a vezető helyre. A színmagyar vidékek képzőjében egyenrangú volt a német-magyar nyelv. Nemzetiségi területeken, pedig a német nyelv mellett az illető nemzetiségi nyelv is helyet kapott. [...] A pesti képzőkben 1856-57-től pedig csupán német volt a tanítási nyelv egészen 1860-61-ig” (Szakál, 1934, p. 57).

Az 1868-as népoktatási törvény is kimondta, hogy „Minden növendék anyanyelvén nyerje az oktatást, amennyiben ez a nyelv a községben divatozó nyelvek egyike." (Báthory \& Falus, 1997, p. 559).

1869-ben megalakultak az első állami tanítóképzők Magyarországon. Az 1870es években az ország peremvidékein 3 tanítóképzőben többnyelvủ képzés indult: Modoron magyar, német, szlovák, Déván: magyar-román, Zniováralján magyarszlovák. A német nyelv tanításának ügye csak részben nemzetiségi kérdés, hiszen majdnem 100 éven át kötelező tárgy volt a német, melyet minden évfolyamon leg- 
alább heti 2 órában kötelező volt tanulni. A képesítő vizsgálatok döntöttek csak a német nyelv nemzetiségi nyelvként való tanulásáról. Külön vizsgaként lehetett a második világháborúig német nyelvű iskolákra is képesítést szerezni. Ugyanúgy, mint a dalmát, szerb, illetve horvát nyelveken (Rácz Fodor, 1993, p 131). 1872-ben miniszteri rendelet szabályozta az állami képzők tanítási nyelvét, amelyekben ezután kötelezővé tette a magyar nyelvet a dévai és a modori képzők kivételével (Rácz Fodor, 1993, p. 132).

\section{A fordulat éve - 1879}

1879-ben jelentős változás állt be a tannyelv kérdésében. Addig a tanítóképezdék követelményrendszerében az anyanyelv preferenciát élvezett a magyar nyelvvel szemben (Nagy, 1993, p. 254). 1879-ben Trefort Ágoston a nemzetiségek érdekeit sértő törvényt alkotott: „Minden akár felekezeti akár másnemű oly tanítóképző intézetekben, amelyekben a tanítás nyelve nem magyar - a magyar nyelv oly óraszámban tanítandó, hogy azt az egész tanfolyam alatt minden tanítójelölt beszédben és írásban elsajátíthassa...” - „tanítóul nem alkalmazható, aki a magyar nyelvet el nem sajátította..." (Rácz Fodor, 1993, p. 132-133).

A törvényjavaslat tárgyalása során számos képviselő adott hangot aggodalmának, kifejezve, hogy félti a nemzetiségek nyelveit, kultúráját és az egyházak autonómiáját (Kéri, 1996). Az 1882 után végzettek közül sem tanítóul, sem segédtanítóul nem alkalmazható, aki a magyart ezen a szinten nem bírja (Nagy, 2005, p. 81). Ez a szabályozás jelentős hatással volt a képzők tannyelvére. „Az 1879-es törvény igen keményen érintette a felekezeti iskolafenntartást, hiszen a görögkeleti egyházak szerb, illetve román tannyelven, az evangélikus egyház pedig részben német tannyelven képzett tanítókat” (Nagy, 2005, p. 81).

\section{A tanítás nyelve - 1880/1881}

Az 1880/81. tanévben a 68 magyarországi képzőből 52-ben magyar lett a tannyelv, 5 evangélikus preparandiában német, 3 katolikus és 1 evangélikus preparandiában magyar-német, 2 görögkeleti és 1 görög katolikus intézetben román, 1 római és 1 görög katolikus intézetben magyar és román, a zombori görögkeleti képzőben szerb, az ungvári görög katolikus iskolában magyar-ruszin. A képzők csupán 23,5\%-ban folyt nem magyar nyelvủ vagy kétnyelvü oktatás (Donáth, 2008, p. 16).

Egy 1892-es szabályozás megnehezítette az állami képzőkben végző nemzetiségi tanítójelöltek helyzetét, a neveléstani írásbeli értekezést magyar nyelven kellett elkészíteniük, ezt pedagógia és magyar szakos tanár is vizsgálta, és bukás is 
lehetett a következménye a nem megfelelő nyelvi szintű dolgozatnak (Nagy, 1993, p. 255).

\section{A tanítás nyelve - a 20. század elsó felében}

Az 1907/08. tanévben a 82 magyarországi tanító(nő)képzőből 72-ben magyar volt a tannyelv. 2 evangélikus intézetben német, 3 görögkeleti és 1 görög katolikus iskolában román, 2 görögkatolikusban magyar és román, a zombori képző(k)ben szerb. A nem magyar, illetve vegyes tannyelvű képzők aránya 23,5\%-ról 12,2\%-ra csökkent (Donáth, 2008, p. 32).

Plasztikusan mutatja a magyar oktatáspolitika törekvéseit, akkori szerepfelfogását, hogy az állami képzők csak a kétnyelvű képzésben vettek részt. A nemzetiségi identitás megőrzésére szolgáló nem magyar nyelvü képzést a felekezeti iskolákra hagyták. Közülük egy sem esett a későbbi trianoni Magyarország területére, aminek a következő két évtized nemzetiségi tanítóképzésére (annak hiányára) is hatása lehetett (Donáth, 2008, p. 55).

Az 1917/1918. tanévre sem változott érdemben a helyzet: a 89 képzőből 77-ben folyt magyar nyelvű oktatás. Nagyszebenben és Segesváron németül, Zomborban szerbül, Aradon, Balázsfalván, Karánsebesen, Lugoson és Nagyszebenben románul, Nagyváradon és Szamosújváron magyarul és románul, míg Szepeshelyen magyarul és szlovákul tanítottak. Így a képzők kb. 13,5\%-ában oktattak nemzetiségi nyelven (is) (Donáth, 2008, p. 32). A trianoni békeszerződést követően az országban nem maradt nem magyar tanítási nyelvü képző, a határokon kívül maradtak a nemzetiségi képzők és diákjaik (Neszt, 2014).

Az „1925/26. tanévtől heti 4 órás nemzetiségi tanfolyamokat szerveztek kezdetben 6, majd a harmincas évektől 7-9 tanító-, ill. tanítónőképző intézetben (köztük a budapesti állami képzőkben). Az első években 150-200, majd afeletti hallgatói létszámmal mủködött - igencsak eltérő színvonalú - tanfolyamok eredményeként évente 22-90 jelölt szerzett képesítést a programba bevont intézményekben (1925 és 1933 között összesen 342 fö)." (Donáth, 2008, p. 108).

1933. május 9-én Bleyer Jakab nagy vihart kavart deklarációt olvasott fel a Képviselőházban. Ebben leszögezte: „sajnos az a tényleges helyzet, hogy [...] nincs egyetlen tanítóképző sem, ahol a német kisebbségi iskolák számára a német nyelv szempontjából csak távolról is megfelelő tanítók képeztetnének ki” (Donáth, 2008, p. 110).

Ez a helyzet változott meg 80 éve, mikor 1939-től nemzetiségi tanítóképzőként mủködött a Magyar Királyi Állami Németnyelvú Tanítóképző Líceum a budai állami 
tanítóképző akkori, Fery Oszkár utca 40. számú épületében (ma Kiss János altábornagy utca) (Donáth, 1998).

Ennek tehát az a jelentősége, hogy állami képzőként működött, a nemzetiségi tanítók képzését felvállalva - eltérően a korábbi gyakorlattól, amikor csak egyházi képzők képeztek nemzetiségi tannyelven. Lux Gyula személyében megbízott igazgató került a budapesti német nyelvű tanítóképző élére (Donáth, 1998, 41).

Német nyelvủ hazai tankönyvek hiányában átmenetileg a mennyiségtant, a természetrajzot, a csillagászati és fizikai földrajzot osztrák, illetve német tankönyvekből tanították, ám a történelem és a német nyelv tanításához saját tankönyveket kívántak írni (Lux Gyula) (Donáth, 1998, p. 43).

Különösen a gyakorlóiskola hiánya okozott problémát, a tanulók kezdetben Budaörsre jártak hospitálni (Donáth, 1998). 1944. április 3-án rendkívüli évvégi osztályozó értekezletre került sor. A Fery Oszkár utcai tanítóképző-intézet épületét 1944. május 15-én hadikórház céljaira adták át (Donáth, 1998, p. 162, 167).

\section{A tanítás nyelve - a második világháború után}

1946-ban a nemzeti kormány úgy rendelkezett, hogy a nemzetiséghez tartozó tanulókat anyanyelven folyó oktatásban kell részesíteni. Az anyanyelvi oktatást állami iskolák létesítésével és fenntartásával, illetőleg államsegély nyújtásával kell biztosítani (1. §) (Föglein, 2004). Az 1949. évi XX. törvény, a Magyar Népköztársaság alkotmánya is biztosította minden nemzetiség számára az anyanyelvén való oktatásnak és nemzeti kultúrája ápolásának lehetőségét (49. §).

A törvényi szabályozás adta keretek között megindult a horvát, szerb, szlovák és a német középfokú tanító(nő)képzés. 1946-ban Pécsett megnyílt a Délszláv Tanítóképző, amelyben horvát és szerb tanítókat képeztek (Fehér, 1993). 1954-ben az első szlovák tanítókat a budapesti szlovák tanítóképző bocsátotta ki (Drahos \& Kovács, 1991). 1955-ben Pécsett, az Állami Teleki Blanka Tanítónőképzőben német nyelvü tanítónőképzés indult, a beiskolázás országos volt.

1950 után a nemzetiségi iskolák nyelvtanítóit tanfolyamon is képezték, majd Pécsett megindult a délszláv nyelvű kiegészítő képzés. 1958-tól lehetőség volt képesítőzni : „... ha a magyar nyelven kívül más nyelven való általános iskola működésre jogosító képesítést is kívánnak szerezni (délszláv, német, szlovák, román nyelven) olyan tanítóképzőkben, ahol a választott nyelvet eddig is rendszeresen tanították." (Rácz Fodor, 1993, p. 139). Ezután már csak a kijelölt nemzetiségi kép- 
zőkben volt erre lehetőség. Ezek a budapesti (délszláv, szlovák), a pécsi (német) és a gyulai (román) tanítóképzők voltak (Rácz Fodor, 1993, 140).

Az 1958-as 26. sz. rendelet Felsőfokú Tanítóképző Intézetek létrehozásáról intézkedett. A Minisztérium által kijelölt intézményekben volt lehetséges a nemzetiségi nyelvü tanulmányok folytatása és oklevél szerzése. A végrehajtási utasítás Budapesten szlovák és szerbhorvát tanítói, Szarvason szlovák, szerbhorvát és román óvónői, Sopronban német óvónői oklevél megszerzésére adott lehetőséget. (Rácz Fodor, 1993, p. 140).

\section{9 - a tanítóképzés felsőfokúvá válása}

60 éve a tanítóképzés felsőfokúvá vált, Felsőfokú Tanítóképző Intézeteket hoztak létre, melyek közül a minisztérium által kijelölt intézményekben lehetett nemzetiségi nyelvủ tanítóképzésben részt venni. A középfokú nemzetiségi tanítóképzők felsőfokú intézetekké történő átszervezésével megszűnt a nemzetiségi nyelven való alapképzés. 1960-tól a Bajai Felsőfokú Tanítóképző Intézetben dél-szláv (szerbhorvát) és német nyelvű tanítóképzés indult. 1972/73-ban szlovák nemzetiségi tanítóképzés indult az Esztergomi Tanítóképző Intézetben (Horváthné Farkas, 2012). 1976-tól Debrecenben román, Szombathelyen szlovén nyelvű tanítók képzésére volt lehetőség (Nagy, 1979, 256). 1986-ban Békéscsabán román tanítóképzés indult. 1990-ben Esztergomban német nemzetiségi tanítóképzés indult (Horváthné Farkas, 2012), ugyanebben az évben a Budapesti Tanítóképző Főiskolán 4 éves kétnyelvű (magyar-német nemzetiségi) általános iskolai tanító szak, 1998-ban pedig magyar-szerb nemzetiségi tanítóképzés indult. 2007-ben Szekszárdon, a Pécsi Tudományegyetembe integrálódott Illyés Gyula Főiskolán német nemzetiségi tanító szakirány indult.

\section{Nemzetiségi törvények}

A közelmúltban alkotott nemzetiségi törvények megteremtik a nemzetiségi tanítóképzés feltételeit. Az 1993. évi a nemzeti és etnikai kisebbségek jogairól szóló LXXVII. törvény kimondta, hogy a kisebbségek anyanyelvű-anyanyelvi oktatásához az anyanyelvű pedagógusok képzésének biztosítása állami feladat (Márkus, 2006, 2007). A 2011. évi, jelenleg hatályos CLXXIX. törvény nemzetiségek jogairól szintén kimondja, hogy a nemzetiségi anyanyelvü és anyanyelvi közneveléshez az anyanyelvủ pedagógusok képzésének, továbbképzésének biztosítása állami feladat. 


\section{Bolognai-rendszer}

A Bolognai-rendszer kedvezőtlen változásokat hozott a nemzetiségi tanítóképzés számára: a nemzetiségi pedagógus szakok szakiránnyá lettek, a nyelvi órák száma jelentősen csökkent. Az alapfokozat megszerzéséhez összegyűjtendő kreditek száma tanító szakon 240 kredit. A nemzetiségi tanító szakképzettségnél a képzési és kimeneti követelmények által meghatározott kreditszám a nemzetiségi nyelv és tantárgy-pedagógiája; a nemzetiségi ismeretek és tantárgy-pedagógia; a nemzetiségi irodalom, gyermekirodalom számára 36-42 kredit. Ez a kredit- és az ezzel ös zszefüggő óraszám nagyon kevés ahhoz, hogy a nemzetiségi anyanyelvi képzés számára kedvező feltételeket teremtsünk.

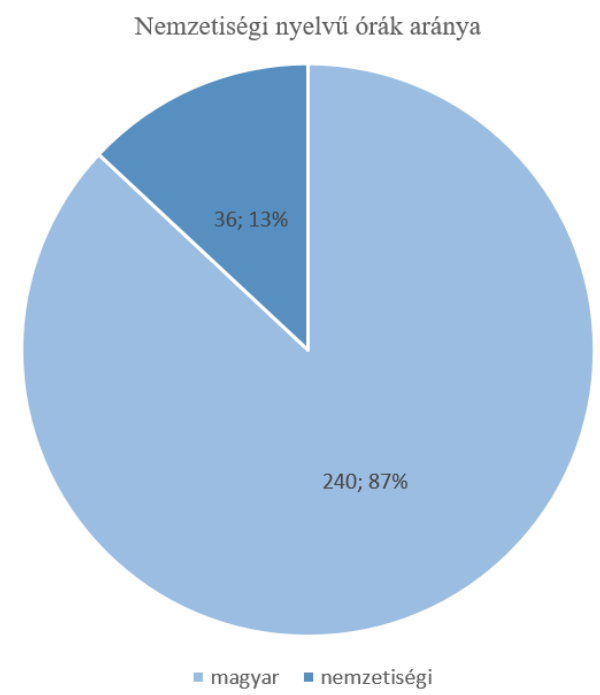

1. ábra: A nemzetiségi nyelvű órák aránya a tanítóképzésben 2019-ben

\section{Nemzetiségi tanítóképzés - 2019}

A felvi.hu adatai szerint a következő 7 képzőben (3 egyházi és 4 állami fenntartásúban) folyik 2019-ben nemzetiségi tanítóképzés a következő nyelveken (intézmény neve, nemzetiségi tanítóképzés, helyszín):

1. Apor Vilmos Katolikus Főiskola: cigány-roma, német. Vác.

2. Eötvös József Főiskola: cigány-roma, horvát, német. Baja.

3. Eötvös Loránd Tudományegyetem Tanító- és Ovvóképző Kar, német² ${ }^{2}$ szerb. Budapest.

${ }^{2}$ A képzésekről bővebben lásd Márkus 2016 és Márkus \& Radvai 2017. 
4. Gál Ferenc Főiskola Pedagógiai Kar: cigány-roma, német, román, szlovák. Szarvas.

5. Pázmány Péter Katolikus Egyetem Bölcsészet- és Társadalomtudományi Kar: német, szlovák. Esztergom.

6. Pécsi Tudományegyetem Kultúratudományi, Pedagógusképző és Vidékfejlesztési Kar: német. Szekszárd.

7. Szegedi Tudományegyetem Juhász Gyula Pedagógusképző Kar: német, román, szlovák. Szeged.

\section{Összefoglalás}

A 200 év történetét összefoglalva a következő mérföldköveket határozhatjuk meg: 1819-ben még nemzetiségi anyanyelvi tanítóképzés folyt a nemzetiségek számára az általuk lakott területeken. 1879-ben a magyar nyelvtörvény által nyert tért a tanítóképzőkben, a nemzetiségi területek tanítóképzőiben is. 1959-ben a középfokú nemzetiségi tanítóképzők felsőfokú intézetekké történő átszervezésével megszűnt a nemzetiségi nyelven való alapképzés.

Napjainkra annyira előrehaladt az asszimiláció, hogy második nyelvként kell a nemzetiségi gyerekek számára saját nemzetiségi anyanyelvüket közvetíteni. A nemzetiségi tanítóképzésnek is erre kell a leendő tanítókat felkészítenie. De a nemzetiségi tanítóképzés jelenleg a magyar nyelvü tanító szak célnyelvi szakiránya, csak a szakirány csekély óraszámában van lehetőség nemzetiségi nyelvü órákat tartani.

A nemzetiségi óvóképzés támogatására a Miniszterelnökség és a Bethlen Gábor Alapkezelő Zrt. által támogatott Nemzetiségi Óvodapedagógus Tanulmányi Ösztöndíj Program indult 2019-ben, amit ez év ősztől a nemzetiségi tanítóképzés támogatására kiterjesztettek. A nemzetiségi szervezetek figyelemfelhívása nyomán az állam felismerte, hogy az utolsó pillanatban vagyunk a nemzetiségi oktatás-nevelés megmentésére.

\section{Kitekintés}

Az ELTE TÓK-on a nemzetköziesítésnek köszönhetően lehetősége van a tanító szakos, német nemzetiségi szakirányos végzett hallgatóinknak német nyelvterületen, Ausztriában tanító MA-diploma megszerzésére, egy intézmények közötti, rektorok által aláírt szerződés nyomán. Ausztriában sok más európai uniós országhoz 
hasonlóan a tanítóképzés mesterszintű. A linzi Pädagogische Hochschule Oberösterreich partnerintézményünk fogadja be a magyar hallgatókat egyéves tanító mesterképzésére. A korábban említett nyelvi szempontból különösen fontos ez a képzési lehetőség, hiszen itt a hallgatók nemzetiségi anyanyelvükön, anyanyelvi környezetben tanulhatnak két féléven át, ami nagyban hozzájárul a nyelvi kompetenciájuk fejlesztéséhez. A 2019/20. tanévben két hallgató kezdte meg tanító MA-tanulmányait Linzben.

\section{Irodalom}

18/2016. (VIII. 5.) EMMI rendelet a felsőoktatási szakképzések, az alap- és mesterképzések képzési és kimeneti követelményeiről, valamint a tanári felkészítés közös követelményeiről és az egyes tanárszakok képzési és kimeneti követelményeiről szóló 8/2013. (I. 30.) EMMI rendelet módosításáról.

https://net.jogtar.hu/jogszabaly? docid=A1 600 018.EMM\&timeshift $=20160$ 813\&txtreferer $=00000$ 001.txt (2019. 09. 30.)

1993. évi LXXVII. törvény a nemzeti és etnikai kisebbségek jogairól http://www.nemzetisegek.hu/dokumentumok/kisebbsegitorveny/kisebbstorvm agyar2006.pdf (2019. 09. 30.)

2011. évi CLXXIX. törvény nemzetiségek jogairól. https://net.jogtar.hu/jogszabaly?docid=A1 100 179.TV (2019. 09. 30.)

Báthory, Z. \& Falus, I. (1997). Pedagógiai lexikon. II. kötet. Keraban Könyvkiadó.

Donáth, P. (1998). Iskola és Politika. Az állami német nemzetiségi tanitóképzés magyarországi történetéhez 1919-1944. Trezor Kiadó.

Donáth, P. (2008). A magyar müvelődés és a tanitóképzés történetéból 1868-1958. Trezor Kiadó. https://mek.oszk.hu/08 200/08 254/ (2019. 09. 30.)

Drahos, Á. \& Kovács P. (1991). A magyarországi nemzeti kisebbségek oktatásügye 1945-1990. Regio - Kisebbségtudományi Szemle, 8(1). pp. 35-64.

Fehér, I. (1993). Az utolsó percben. Magyarország nemzetiségei 1945-1990. Kossuth Könyvkiadó.

https://www.sulinet.hu/oroksegtar/data/magyarorszagi_nemzetisegek/ altalanos/az_utolso_percben/pages/001_kiado.htm (2019. 09. 30.)

Föglein, G. (2004). Nemzetiségi oktatás a Kádár-korszakban. Új Pedagógiai Szemle, 64(9). pp. 2-94.

Horváthné Farkas, É. (2012). Nemzetiségi képzés a Pázmány Péter Katolikus Egyetem Vitéz János Karán. Társadalmi Együttélés, 1(2), pp. 1-16. 
Kéri, K. (1996). Az 1879: XVII. törvénycikktől a „Lex Apponyi”-ig. Adalékok a kötelezó magyar nyelvoktatás történetéhez.

https://kerikatalin.wordpress.com/1997/12/01/az-1879xviii-torvenycikktol-alex-apponyi-ig/ (2019. 09. 30.)

Kiss, J. (1929a). A magyar tanítóképzés statisztikai adatai. Magyar Tanitóképző, 42(1), pp. 22-35.

Kiss, J. (1929b). A magyar tanítóképzés statisztikai adatai. Magyar Tanítóképzó, 42(2), pp. 100-120.

Kovács, K. \& Grundig de Vazques, K. (2011). A magyar és a német népiskolák és a néptanítói szaktudás fejlődése a történelem sorában. Képzés és Gyakorlat, 9(1-2), pp. 31-46.

Márkus, É. (2006). A magyarországi németek oktatási helyzete. In: Bodó, E. (Ed.), „Kulcs Európához” Az idegen nyelvi és német nemzetiségi képzés a tanitóképzés elmúlt 15 évében. p. 47-66. http://mek.oszk.hu/09 100/09188/ (2019. 09. 30.)

Márkus, É. (2007). Kisebbségi oktatás - a magyarországi németek. Fórum Társadalomtudományi Szemle, 9(4). pp. 111-127.

Márkus, É. (2016). Minderheiten in Ungarn und die Ausbildung von Minderheitenpädagogen an der ELTE TÓK. In: Ilse, V. et al. (Ed.): Interkulturalität und Mehrsprachigkeit in den Schulen im Donauraum. p. 81-92.

https://doi.org/10.3726/978-3-653-07 188-7

Márkus, É. \& Radvai, T. (2017). Die PädagogInnenausbildung für Kindergärten und Primarschulen der deutschen Minderheit in Ungarn an der ELTE TÓK. In: Philipp, H. \& Ströbel, A. Deutsch in Mittel-, Ost- und Südosteuropa. Geschichtliche Grundlagen und aktuelle Einbettung. Beiträge zur 2. Fahrestagung des Forschungszentrums Deutsch in Mittel-, Ost- und Südosteuropa, Budapest, 1.-3. Oktober 2015. Regensburg: Verlag Friedrich Pustet: 615-634. (= Forschungen zur deutschen Sprache in Mittel-, Ost- und Südosteuropa FzDiMOS, Band 5).

Márkus, É. \& M. Pintér T. (2019). Kezdetben vala... Szepeskáptalan. Az első német nemzetiségi tanítóképző intézet a történelmi Magyarország területén. Fórum Társadalomtudományi Szemle 21(2), pp. 93-102.

Mészáros, I. (1984). Népoktatásunk szervezeti-tartalmi átalakulása 1777-1830 között. Tankönyvkiadó. (Pedagógiai közlemények 26.)

Nagy, P. T. (1993). Nemzetiség és oktatás a dualizmuskori Magyarországon. Educatio 2(2), pp. 253-269.

Nagy, P. T. (2005). Az állami befolyás növekedése a magyarországi oktatásban 1867-1945. Iskolakultúra, 15(6-7). pp. 3-229.

Nagy, S. (Ed.) (1979). Pedagógiai Lexikon. IV kötet. Akadémiai Kiadó. 
Neszt, J. (2014). A középfokú elemi iskolai tanitóképzők intézményrendszerének kiépülése és változásai 1828-tól 1945-ig. Doktori (Ph.D.) értekezés, Humán Tudományok Doktori Iskola, Debreceni Egyetem.

Rácz Fodor, S. (1993). A nemzetiségi tanítóképzés története (1870-1970). EfTKF Tudományos Közlemények 7. pp. 129-141.

Szakál, J. (1934). A magyar tanítóképzés története. http://mtdaportal.extra.hu/books/szakal_janos_a_magyar_tanitokepzes_torten ete.pdf (2019. 09. 30.)

\section{A brief history of the Hungarian national minority primary teacher education}

The study presents the 200-year history and present of national minority primary teacher education, providing a national context. The history of some teacher training institutes, which are a turning point in the analyzed topic, is presented in more detail. There are two aspects in the analysis that guide the author of the study, addressing the topic of the language of instruction and legislation. Outlines steps to change the language of instruction and outlines key laws that have impacted and are affecting primary teacher education for nationalities.

Keywords: national minorities, primary teacher training, primary teacher training colleges, language teaching, language of instruction, legal regulations 